\title{
Case study: successful recovery from anorexia nervosa in a 19yr old patient using manualised FBT
}

Kellie Lavender

From 2014 ANZAED Conference: Driven Bodies Driven Brains

Fremantle, Australia. 22-23 August 2014

At the Regional Eating Disorders Service (REDS) in Auckland Family Based Treatment (FBT) is the first line treatment offered to adolescents and their families - and with great success. At REDS we are also offering a choice to individuals over 18 and their families between FBT and individual treatment in an adult part of the service. This presentation describes a successful example of a client case study where FBT was provided with a $19 \mathrm{yr}$ old Japanese woman and her family. The case presented with some initial challenges like beginning treatment with a BMI of 14.9, parents needing interpreters and the family living $40 \mathrm{~km}$ away.

There is no evidence for the effectiveness of FBT for young adults; however in a case series published by Chen., LeGrange et al. (2010) they describe how FBT was used with 4 older clients with $3 / 4$ at follow up being in the normal weight range. The presenter raises the question about whether services should offer FBT as a choice to those over 18 years and living at home and willing to have their family involved.

This presentation will also discuss the question about whether there is a need to consider modifications to FBT with this older age group. A summary of data of FBT cases with young adults at REDS will be provided.

This abstract was presented in the Treatment in Community and Inpatient Settings stream of the 2014 ANZAED Conference.

Submit your next manuscript to BioMed Central and take full advantage of:

- Convenient online submission

- Thorough peer review

- No space constraints or color figure charges

- Immediate publication on acceptance

- Inclusion in PubMed, CAS, Scopus and Google Scholar

- Research which is freely available for redistribution
() Biomed Central

Regional Eating Disorders Service, Auckland, New Zealand 